\title{
Precision Nitrogen Management in Bt Cotton (Gossypium hirsutum) Improves Seed Cotton Yield and Nitrogen Use Efficiency, and Reduces Nitrous Oxide Emissions
}

\author{
Rajeev Kumar Gupta ${ }^{1}$ D, Arun Shankar ${ }^{2}$, Bijay-Singh ${ }^{1}\left(\mathbb{D}\right.$, Rajan Bhatt $^{1}{ }^{\mathbb{D}}$, Asma A. Al-Huqail ${ }^{3}$, \\ Manzer H. Siddiqui ${ }^{3, *}$ and Ritesh Kumar ${ }^{4}$ \\ 1 Department of Soil Science, Punjab Agricultural University, Ludhiana 141004, India; \\ rkg1103@pau.edu (R.K.G.); bijaysingh20@hotmail.com (B.-S.); rajansoils@pau.edu (R.B.) \\ 2 Department of Soil Science, GNS University, Rohtas 821305, India; aspauldh@gmail.com \\ 3 Department of Botany and Microbiology, College of Science, King Saud University, \\ Riyadh 11451, Saudi Arabia; aalhuqail@ksu.edu.sa \\ 4 Department of Agronomy, Kansas State University, Manhattan, KS 66506, USA; ritesh1@ksu.edu \\ * Correspondence: mhsiddiqui@ksu.edu.sa
}

check for updates

Citation: Gupta, R.K.; Arun Shankar; Bijay-Singh; Bhatt, R.; Al-Huqail, A.A.; Siddiqui, M.H.; Kumar, R.

Precision Nitrogen Management in Bt Cotton (Gossypium hirsutum) Improves Seed Cotton Yield and Nitrogen Use Efficiency, and Reduces Nitrous Oxide Emissions.

Sustainability 2022, 14, 2007.

https://doi.org/10.3390/su14042007

Academic Editors: Muhammad

Zafar-ul-Hye, Shah Fahad and

Muhammad Shaaban

Received: 16 January 2022

Accepted: 4 February 2022

Published: 10 February 2022

Publisher's Note: MDPI stays neutral with regard to jurisdictional claims in published maps and institutional affiliations.

Copyright: () 2022 by the authors Licensee MDPI, Basel, Switzerland. This article is an open access article distributed under the terms and conditions of the Creative Commons Attribution (CC BY) license (https:// creativecommons.org/licenses/by/ $4.0 /)$.

\begin{abstract}
Field experiments were conducted to establish precision $\mathrm{N}$ management technology for nitrogen $(\mathrm{N})$ topdressings in Bt (Bacillus thuringiensis) cotton (Gossypium hirsutum) along with the quantification of nitrous oxide emissions from the soil. The treatments consisted of five fixed $\mathrm{N}$ rates $\left(0,60,90,120\right.$ and $150 \mathrm{~kg} \mathrm{~N}$ ha $^{-1}$ applied in two split doses) and eight site-specific $\mathrm{N}$ management (SSNM) treatments of applying different $\mathrm{N}$ rates at 40 days after sowing (DAS) and the application of leaf colour chart (LCC)-guided 30,45 or $60 \mathrm{~kg} \mathrm{~N} \mathrm{ha}^{-1}$ at 55 DAS only in four treatments and at both 55 and 85 DAS (first flowering and boll formation stages) in the remaining four treatments. A higher $\mathrm{R}^{2}$ value between the total $\mathrm{N}$ uptake and the leaf $\mathrm{N}$ concentration at 85 DAS than at 55 DAS strongly suggested that fertilizer $\mathrm{N}$ management based on leaf $\mathrm{N}$ concentration measured in terms of LCC scores led to an adequate total $\mathrm{N}$ uptake resulting in a respectable yield. Topdressings of 45 to $60 \mathrm{~kg} \mathrm{~N} \mathrm{ha}^{-1}$ at 40 DAS and an LCC-based application at 55 DAS produced seed cotton yields on a par with the addition of $150 \mathrm{~kg} \mathrm{~N} \mathrm{ha}^{-1}$ based on a soil test basis along with an improved recovery and agronomic efficiency use, and remarkably lowered the nitrous oxide emissions as estimated using the CCAFS (Climate Change, Agriculture and Food Security)-Mitigation Option Tool.
\end{abstract}

Keywords: leaf colour chart; nitrogen use efficiency; nitrous oxide emissions; growth stages of cotton; leaf greenness; Bt cotton

\section{Introduction}

An inadequate supply of nitrogen $(\mathrm{N})$ to Bt (Bacillus thuringiensis) transgenic cotton hybrids impacts not only their yield but also protein synthesis and metabolism, which is critical in transgenic crops as it can potentially alter the cry toxin expression [1]. Due to a large variation in soil fertility in northern India, the standard blanket region-wide fertilizer $\mathrm{N}$ recommendation leads to an $\mathrm{N}$ application in excess of the needs of the crop in many cases, resulting in low fertilizer $\mathrm{N}$ use efficiency and enhanced nitrous oxide emissions from the soil to the environment [2]. Cotton growers mostly do not take the risk of low yields due to limiting $\mathrm{N}$ and apply subsidized fertilizer $\mathrm{N}$ above the standard recommendation. Little attention is paid to low $\mathrm{N}$ use efficiency and the damage that can be done to the environment or soil health. In north-western India, the standard fertilizer $\mathrm{N}$ recommendation for $\mathrm{Bt}$ cotton consists of broadcasting a fertilizer $\mathrm{N}$ dose of $75 \mathrm{~kg} \mathrm{ha}^{-1}$ at about 40 days after sowing (DAS) when at each hill only one plant is retained and another $75 \mathrm{~kg} \mathrm{~N}$ at 55 DAS i.e., the first flowering stage [3]. Need-based $N$ management strategies help to synchronize the fertilizer $\mathrm{N}$ supply and crop demand and thereby maximize the $\mathrm{N}$ uptake. 
The optimization of fertilizer $\mathrm{N}$ use in field crops can be achieved by synchronizing crop $\mathrm{N}$ demand with the supply of $\mathrm{N}$ from all $\mathrm{N}$ sources on a field-specific basis during the cropping season [4]. To replace the blanket fertilizer recommendations designed for a region with similar soil and climate attributes, this approach can meet the $\mathrm{N}$ needs of crops by applying $\mathrm{N}$ at the appropriate crop growth stages in order to achieve optimum yield levels. In large fields in developed countries, it is now possible to achieve site-specific $\mathrm{N}$ management (SSNM) through variable-rate fertilizer $\mathrm{N}$ applicators using crop sensors. However, for smallholder farmers in developing countries these expensive implements/machines are not appropriate. Smallholder farmers in developing countries often use the intensity of the green colour of the leaves of crop plants as a subjective indicator of the $\mathrm{N}$ needs of the crops. However, visual estimates of the greenness of leaves are often influenced by sunlight variability and human bias [5].

To quantify the site-specific $\mathrm{N}$ needs of field crops in real-time, an estimation of the $\mathrm{N}$ status of the leaves in terms of the chlorophyll content or leaf greenness is valuable [6]. In recent decades, this has been accomplished by using hand-held chlorophyll meters, which interpret the colour of the leaves in terms of the relative chlorophyll content. However, due to the prohibitive cost of chlorophyll meters, farmers in developing countries now use a leaf colour chart (LCC) to quantify the leaf colour to assess the relative quantity of chlorophyll (leaf greenness) or $\mathrm{N}$ in the leaves. It is a low-cost tool for estimating the leaf $\mathrm{N}$ status and consists of a plastic sheet with six panels with a range of green colours varying from light green to dark green. By comparing the reflection of the light from the leaf surface and different panels on the LCC, the relative leaf $\mathrm{N}$ status is estimated in terms of leaf greenness [7]. A large number of studies on field-specific $\mathrm{N}$ management in cereal crops have demonstrated the usefulness of LCCs [2].

As per the recent quantification of global nitrous oxide $\left(\mathrm{N}_{2} \mathrm{O}\right)$ sources and sinks undertaken by Tian et al. [8], $\mathrm{N}_{2} \mathrm{O}$ emissions due to human activities have increased from $5600 \mathrm{Gg} \mathrm{N}$ annually in the 1980 s to $7300 \mathrm{Gg} N$ annually in 2007 to 2016 . More than $70 \%$ of this increase has come from direct emissions from fertilizer applications in agriculture. As the efficient management of fertilizer $\mathrm{N}$ is the one of the major strategies to reduce $\mathrm{N}_{2} \mathrm{O}$, it is expected that shifting soil test-based $\mathrm{N}$ management to SSNM should lead to reduced $\mathrm{N}_{2} \mathrm{O}$ emissions.

Several studies on site-specific $\mathrm{N}$ fertilizer management in cotton based on the leaf $\mathrm{N}$ status as measured by chlorophyll meters are available in the literature [9-13]. Keeping in view the low cost of the LCC and its ease of use by farmers, the major objective of the present study was to develop protocols for using the 6-panel LCC standardized by the Punjab Agricultural University to apply crop need-based fertilizer $\mathrm{N}$ applications in a given field at different growth stages of Bt cotton. As the LCC can be used only when the crop is already growing in the field, an important aspect of the experiments planned for this study was to find the appropriate basal dose as well as its addition before applying the LCC-guided dose of nitrogen. Using the Climate Change, Agriculture and Food SecurityMitigation Option Tool (CCAFS-MOT), $\mathrm{N}_{2} \mathrm{O}$ emissions from different SSNM strategies were also compared with region-specific fixed fertilizer $\mathrm{N}$ recommendations.

\section{Materials and Procedures}

\subsection{The Location and Climate of the Experimental Fields}

The experiments took place at the research farm of the Punjab Agricultural University in Ludhiana, Punjab, India. The experimental site $\left(30^{\circ} 56^{\prime} \mathrm{N}\right.$ latitude and $75^{\circ} 23^{\prime} \mathrm{E}$ longitude) is located in the state of Punjab in the Trans-Gangetic agro-climatic zone. The climate of the experimental site is subtropical and semi-arid. During May and June, the temperature in summer may reach $45{ }^{\circ} \mathrm{C}$ with hot and dry weather. The average annual rainfall at the experimental location is $742 \mathrm{~mm}$, with $75 \%$ of that falling between July and September. 


\subsection{Weather during the Cotton Season}

Figure 1 shows the meteorological data recorded at the meteorological observatory of the Punjab Agricultural University in Ludhiana during the crop growing seasons according to conventional meteorological weeks. The mean weekly maximum and minimum temperatures during kharif 2016 ranged from 33.1 to $42.6^{\circ} \mathrm{C}$ and 19.7 to $29.2^{\circ} \mathrm{C}$, respectively, whereas in kharif 2017 , the corresponding ranges were 32 to $39.2^{\circ} \mathrm{C}$ and 21.0 to $28.5^{\circ} \mathrm{C}$, respectively. The maximum weekly rainfall $(152.4 \mathrm{~mm})$ was received in the 26 th standard meteorological week during kharif 2016 whereas in kharif 2017, it was $100 \mathrm{~mm}$ and was received in the 35th standard meteorological week. The mean weekly sunshine hours ranged from 1.1 to 12 and 3.6 to $11 \mathrm{~h}$ per day during kharif 2016 and 2017, respectively. During May and October, when the cotton was grown, the average monthly maximum and minimum temperatures varied between 33.4 and $41.0^{\circ} \mathrm{C}$ and 17.2 and $26.9^{\circ} \mathrm{C}$, respectively. During the cotton growing season, the average total rainfall was $612 \mathrm{~mm}$.
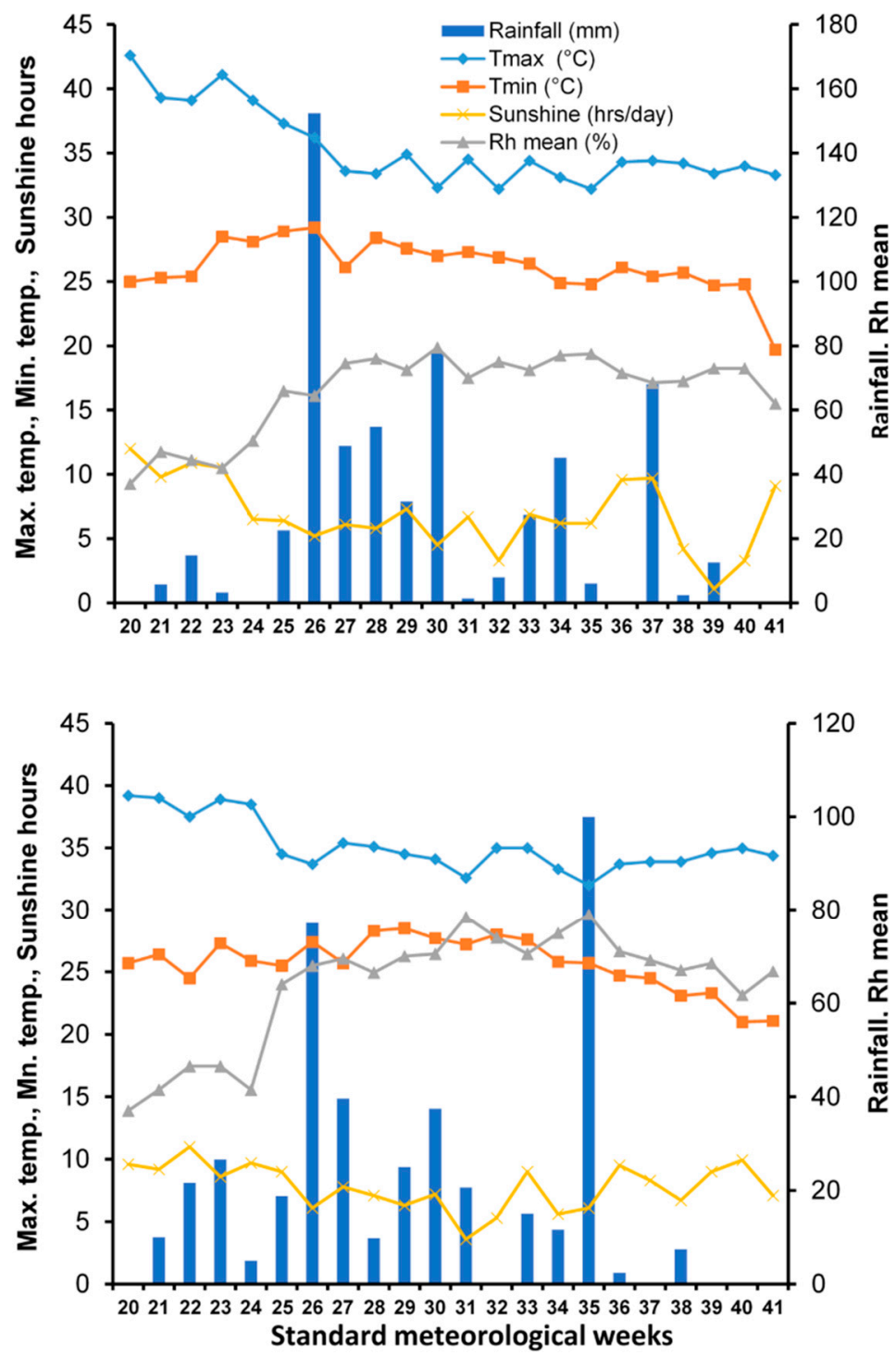

Figure 1. Weekly mean meteorological data during the kharif 2016 and kharif 2017 cropping seasons.

\subsection{Experimental Site and Soil Characteristics}

During 2016 and 2017, two field experiments were conducted in the same experimental field, which had a cotton-wheat crop rotation during 2015. Table 1 shows the physicochemical parameters of $0-15 \mathrm{~cm}$ soil sampled before initiating the experiment in 2016 . The soil in the $0-0.15 \mathrm{~m}$ depth in the field was sandy loam (76\% sand, $13 \%$ silt and $11 \%$ clay), 
$\mathrm{pH} 7.3$ and EC $0.30 \mathrm{dS} \mathrm{m}^{-1}$ [14]. The soil organic carbon content [15] was $3.1 \mathrm{~g} \mathrm{~kg}^{-1}$ The accessible P of Olsen was $5.36 \mathrm{mg} \mathrm{P} \mathrm{kg}^{-1}$ and the extractable $\mathrm{K}$ of ammonium acetate was $96 \mathrm{mg} \mathrm{kg}^{-1}$ [14].

Table 1. Physico-chemical characteristics of $0-15 \mathrm{~cm}$ soil sample collected at the initiation of the experiment.

\begin{tabular}{|c|c|}
\hline Parameters & Values \\
\hline Sand $(\%)$ & 76.0 \\
\hline Silt (\%) & 13.0 \\
\hline Clay $(\%)$ & 11.0 \\
\hline Available $\mathrm{N}\left(\mathrm{kg} \mathrm{ha}^{-1}\right)$ & 145 \\
\hline $\mathrm{pH}$ (1:2 soil solution ratio) & 7.3 \\
\hline EC $\left(\mathrm{dSm}^{-1}\right)$ (1:2 soil solution ratio) & 0.29 \\
\hline Soil organic carbon $(\%)$ & 0.30 \\
\hline Olsen's P $\left(\mathrm{kg} \mathrm{ha}^{-1}\right)$ & 12.1 \\
\hline Ammonium acetate extractable $\mathrm{K}\left(\mathrm{kg} \mathrm{ha}^{-1}\right)$ & 221.0 \\
\hline
\end{tabular}

\subsection{Soil and Crop Management}

In both 2016 and 2017, before establishing the experiments, the fields were levelled after two ploughing rounds and irrigated with about a $100 \mathrm{~mm}$ depth of irrigation. Once the field capacity $(23 \%)$ level of soil moisture was achieved, the fields were ploughed, levelled and divided into 39 experimental plots each measuring $8.25 \times 5.40 \mathrm{~m}^{2}$. A randomised block design was employed with 13 treatments and was replicated thrice. Bt cotton (cv. RCH 650) was sown in rows in the first week of May in both the years. The spacing between the rows was maintained at $67.5 \mathrm{~cm}$. The distance between two plants in a row was kept at $75 \mathrm{~cm}$. One plant per hill was kept after 40 days of planting. In different treatment plots, fertilizer $\mathrm{N}$ as urea was applied to the cotton as per the treatment. Phosphorus and potassium were applied as a basal dose of $187.5 \mathrm{~kg}$ single super phosphate and $50 \mathrm{~kg}$ muriate of potash per acre at the time of sowing. $\mathrm{N}$ was applied as urea in all treatments and at various phases of the growth of the crop. During both 2016 and 2017, three flood irrigations each of $75 \mathrm{~mm}$ depth were applied to the cotton as and when required depending on rainfall events. Standard procedures as described by the Punjab Agricultural University [3] were followed to control pests, diseases and weeds.

\subsection{Description of the Treatments}

The $\mathrm{N}$ levels in the treatments T1 to T5 were graded: no N control, 60, 90, 120 and $150 \mathrm{~kg} \mathrm{~N} \mathrm{ha}^{-1}$. The first dose $(75 \mathrm{~kg} \mathrm{~N})$ was administered at 40 DAS and a similar dose at 55 DAS. Treatments T6 to T13 of the SSNM comprised applying 30, 45, 60 and $75 \mathrm{~kg} \mathrm{~N} \mathrm{ha}^{-1}$ at 40 DAS and applying LCC-guided 30,45 or $60 \mathrm{~kg} \mathrm{~N} \mathrm{ha}^{-1}$ only at 55 DAS (treatments T6, T8, T10 and T12) and both at 55 and 85 DAS (treatments T6, T8, T10 and T12 and treatments T7, T9, T11 and T13, respectively). At 55 DAS, either 30,45 or $60 \mathrm{~kg} \mathrm{~N} \mathrm{ha}^{-1}$ was applied if the greenness of the fourth fully expanded leaf from the top was more than an LCC score of 4.1 , between 3.8 and 4.1 or less than 3.8 , respectively (adjustable dose 1 or $\mathrm{Ad}_{1}$ ). After 85 days of planting, the decision to apply 30,45 or $60 \mathrm{~kg} \mathrm{~N}$ ha $^{-1}$ was made depending on whether the greenness of the fourth fully expanded leaf from the top was more than an LCC score of 4.0, between 3.7 and 4.0 or less than 3.7, respectively (adjustable dose 2 or $\mathrm{Ad}_{2}$ ). Table 2 shows the amount of fertiliser $\mathrm{N}$ administered in various treatments at 40 DAS and as adjustable doses based on the criteria for $\mathrm{Ad}_{1}$ at $55 \mathrm{DAS}$ and $\mathrm{Ad}_{2}$ at $85 \mathrm{DAS}$. The LCC readings pertaining to the upper fourth leaf were used, aiming at guiding the fertilizer $\mathrm{N}$ application at $55 \mathrm{DAS}\left(\mathrm{Ad}_{1}\right)$ and at $85 \mathrm{DAS}\left(\mathrm{Ad}_{2}\right)$ as per the critical LCC scores established in the study carried out by Arun Shankar et al. [16] 
Table 2. Description of the treatments and mean LCC scores recorded at 55 and 85 DAS in different treatments in two years. The adjustable fertilizer $\mathrm{N}$ doses applied in different treatments at 55 DAS $\left(\mathrm{Ad}_{1}\right)$ and at $85 \mathrm{DAS}\left(\mathrm{Ad}_{2}\right)$ were applied using the LCC score at Ludhiana, India in 2016 and 2017.

\begin{tabular}{|c|c|c|c|c|c|c|c|c|c|c|c|}
\hline \multirow{4}{*}{ Treatment } & \multicolumn{7}{|c|}{ Nitrogen Applied (kg ha $\left.{ }^{-1}\right)$} & \multicolumn{2}{|c|}{$\begin{array}{c}\text { Mean LCC } \\
\text { Scores at } 55 \text { DAS }\end{array}$} & \multicolumn{2}{|c|}{$\begin{array}{c}\text { Mean LCC } \\
\text { Scores at } 85 \text { DAS }\end{array}$} \\
\hline & \multicolumn{5}{|c|}{ DAS } & \multirow{2}{*}{\multicolumn{2}{|c|}{ Total }} & \multirow{3}{*}{2016} & \multirow{3}{*}{2017} & \multirow{3}{*}{2016} & \multirow{3}{*}{2017} \\
\hline & \multirow[t]{2}{*}{40} & \multicolumn{2}{|c|}{55} & \multicolumn{2}{|c|}{85} & & & & & & \\
\hline & & 2016 & 2017 & 2016 & 2017 & 2016 & 2017 & & & & \\
\hline T1 (No N control) & 0 & 0 & & 0 & 0 & 0 & 0 & 3.85 & 3.88 & 3.60 & 3.73 \\
\hline $\mathrm{T} 2$ & 30 & 30 & & - & - & 60 & 60 & 4.00 & 4.00 & 3.80 & 3.82 \\
\hline T3 & 45 & 45 & & - & - & 90 & 90 & 4.00 & 4.00 & 4.00 & 4.00 \\
\hline $\mathrm{T} 4$ & 60 & 60 & & - & - & 120 & 120 & 4.12 & 4.13 & 4.05 & 4.03 \\
\hline $\mathrm{T} 5$ & 75 & 75 & & - & - & 150 & 150 & 4.15 & 4.18 & 4.08 & 4.07 \\
\hline T6 & 30 & $\begin{array}{c}45 \\
\left(\mathrm{Ad}_{1}\right)^{\dagger}\end{array}$ & $\begin{array}{c}45 \\
\left(\mathrm{Ad}_{1}\right)\end{array}$ & - & - & 75 & 75 & 4.00 & 4.00 & 3.83 & 3.92 \\
\hline $\mathrm{T} 7$ & 30 & $\begin{array}{c}45 \\
\left(\mathrm{Ad}_{1}\right)\end{array}$ & $\begin{array}{c}45 \\
\left(\mathrm{Ad}_{1}\right)\end{array}$ & $\begin{array}{c}45 \\
\left(\mathrm{Ad}_{2}\right) \\
\ddagger\end{array}$ & $\begin{array}{c}45 \\
\left(\mathrm{Ad}_{2}\right)\end{array}$ & 120 & 120 & 4.00 & 4.00 & 3.80 & 3.93 \\
\hline $\mathrm{T} 8$ & 45 & $\begin{array}{c}45 \\
\left(\mathrm{Ad}_{1}\right)\end{array}$ & $\begin{array}{c}45 \\
\left(\mathrm{Ad}_{1}\right)\end{array}$ & - & - & 90 & 90 & 4.00 & 4.03 & 4.00 & 4.00 \\
\hline T9 & 45 & $\begin{array}{c}45 \\
\left(\mathrm{Ad}_{1}\right)\end{array}$ & $\begin{array}{c}45 \\
\left(\mathrm{Ad}_{1}\right)\end{array}$ & $\begin{array}{c}45 \\
\left(\mathrm{Ad}_{2}\right)\end{array}$ & $\begin{array}{c}45 \\
\left(\mathrm{Ad}_{2}\right)\end{array}$ & 135 & 135 & 4.00 & 4.02 & 4.00 & 4.00 \\
\hline $\mathrm{T} 10$ & 60 & $\begin{array}{c}30 \\
\left(\mathrm{Ad}_{1}\right)\end{array}$ & $\begin{array}{c}30 \\
\left(\mathrm{Ad}_{1}\right)\end{array}$ & - & - & 90 & 90 & 4.13 & 4.12 & 4.00 & 4.00 \\
\hline $\mathrm{T} 11$ & 60 & $\begin{array}{c}30 \\
\left(\mathrm{Ad}_{1}\right)\end{array}$ & $\begin{array}{c}30 \\
\left(\mathrm{Ad}_{1}\right)\end{array}$ & $\begin{array}{c}30 \\
\left(\mathrm{Ad}_{2}\right)\end{array}$ & $\begin{array}{c}30 \\
\left(\mathrm{Ad}_{2}\right)\end{array}$ & 120 & 120 & 4.12 & 4.13 & 4.02 & 4.02 \\
\hline $\mathrm{T} 12$ & 75 & $\begin{array}{c}30 \\
\left(\mathrm{Ad}_{1}\right)\end{array}$ & $\begin{array}{c}30 \\
\left(\mathrm{Ad}_{1}\right)\end{array}$ & - & - & 105 & 105 & 4.15 & 4.17 & 4.02 & 4.02 \\
\hline $\mathrm{T} 13$ & 75 & $\begin{array}{c}30 \\
\left(\mathrm{Ad}_{1}\right)\end{array}$ & $\begin{array}{c}30 \\
\left(\mathrm{Ad}_{1}\right)\end{array}$ & $\begin{array}{c}30 \\
\left(\mathrm{Ad}_{2}\right)\end{array}$ & $\begin{array}{c}30 \\
\left(\mathrm{Ad}_{2}\right)\end{array}$ & 135 & 135 & 4.17 & 4.17 & 4.03 & 4.02 \\
\hline $\operatorname{LSD}(p=0.05)$ & & & & & & & & 0.07 & 0.09 & 0.17 & 0.17 \\
\hline
\end{tabular}

${ }^{+} \mathrm{Ad}_{1}$ : adaptable quantity of 30, 45 or $60 \mathrm{~kg} \mathrm{~N} \mathrm{ha}^{-1}$ depending on LCC score $>4.1$, between 3.8 and 4.1 and $<3.8$, respectively. $\ddagger \mathrm{Ad}_{2}$ : adaptable quantity of 30,45 and $60 \mathrm{~kg} \mathrm{~N} \mathrm{ha}^{-1}$ depending on LCC score $>4.0$, between 3.7 and 4.0 and $<3.7$, respectively.

\subsection{Leaf N Status Measurement, Plant Sampling and Analysis}

The 6-panel LCC designed by the Punjab Agricultural University, Ludhiana (India) and manufactured by Messers N Parameters, Chennai, India (https: / / www.nitrogenparameters. $\mathrm{com} /$ (accessed on 12 January 2022)) was used to assess the leaf $\mathrm{N}$ status by matching the leaf greenness with different green shade panels on the LCC. After 55 and 85 days and after planting in two growth stages of the cotton, the LCC score of the upper fourth fully grown leaf (of ten disease-free uniform plants per plot) was recorded.

At the maturity of the crop in October/November, the seed cotton from different plots was manually picked and the yields were recorded. When the plots were harvested, five uniform stovers from each plot were saved and dried in an oven at $65^{\circ} \mathrm{C}$ to a constant dry weight. The samples of stovers, leaves and seeds of cotton were finely ground and digested with concentrated sulphuric acid. The digests were analysed for total $\mathrm{N}$ following the micro-Kjeldahl method [17]. The total $\mathrm{N}$ uptake at maturity was calculated by multiplying the yield with the $\% \mathrm{~N}$ in different components of the cotton plants. 


\subsection{Estimation of $\mathrm{N}_{2} \mathrm{O}$ Emissions Using CCAFS-MOT}

The Climate Change, Agriculture and Food Security (CCAFS)-Mitigation Option Tool (CCAFS-MOT) was used to estimate the total GHG and $\mathrm{N}_{2} \mathrm{O}$ emissions in terms of the carbon dioxide equivalent per hectare for a given baseline of agricultural management techniques $\left(\mathrm{kg} \mathrm{CO}_{2}\right.$ eq ha $\left.{ }^{-1}\right)$.

\subsection{Statistical Analysis and Calculations}

Statistical package CPCS1 (Punjab Agricultural University, Ludhiana, India) was used to analyse the data recorded from the following ANOVA for a randomized block design. The regression functions between the different variables were established using Microsoft EXCEL.

The sustainable yield index (SYI) was calculated as:

$$
\mathrm{SYI}=(\mathrm{A}-\mathrm{Y}) / \mathrm{Ymax} \times 100
$$

where $\mathrm{A}$ and $\mathrm{Y}$ are the mean and standard deviation, respectively, and $\mathrm{Ymax}$ is the maximum potential yield observed in different treatments.

The agronomic efficiency (AEN) and recovery efficiency (REN) measurements of fertiliser $\mathrm{N}$ use efficiency were computed as stated by Baligar et al. [18]:

$$
\begin{gathered}
\text { AEN (kg grain kg } \left.\mathrm{N} \text { applied }{ }^{-1}\right)=\left(\text { grain yield in } N \text { fertilized plot }- \text { grain }^{\text {yield in zero } N \text { plot }) /(\mathrm{N} \text { fertilizer rate })}\right. \\
\operatorname{REN~}(\%)=(\text { total } \mathrm{N} \text { uptake in } \mathrm{N} \text { fertilized plot }- \text { total } \mathrm{N} \text { uptake in zero } \mathrm{N} \\
\text { plot }) /(\mathrm{N} \text { fertilizer rate }) \times 100 .
\end{gathered}
$$

\section{Results}

\subsection{Relationship between the LCC Score and Leaf N Concentration in Cotton}

The nitrogen concentration increased with an increasing LCC score as recorded from the fourth leaf from the top at both growth stages (55 and 85 DAS) of Bt cotton (Figure 2). The $\mathrm{R}^{2}$ values of the LCC score and leaf $\mathrm{N}$ concentration were greater at 85 DAS than at 55 DAS, indicating that the $\mathrm{R}^{2}$ values of the relationships between the LCC score and leaf $\mathrm{N}$ concentration gave a good indication of the leaf $\mathrm{N}$ status. At $55 \mathrm{DAS}$, the leaf $\mathrm{N}$ concentration ranged between 3.8 and $5.4 \%$; it was between 2.8 and $4.0 \%$ at 85 DAS. Critical LCC scores of 4.1 and 4.0 were established by Arun Shankar et al. [16] to differentiate between the sufficiency and deficiency of $\mathrm{N}$ in Bt cotton at 55 and 85 DAS, respectively; the two different growth stages translated into 4.4 and $3.6 \% \mathrm{~N}$ in the leaf, respectively (Figure 2).

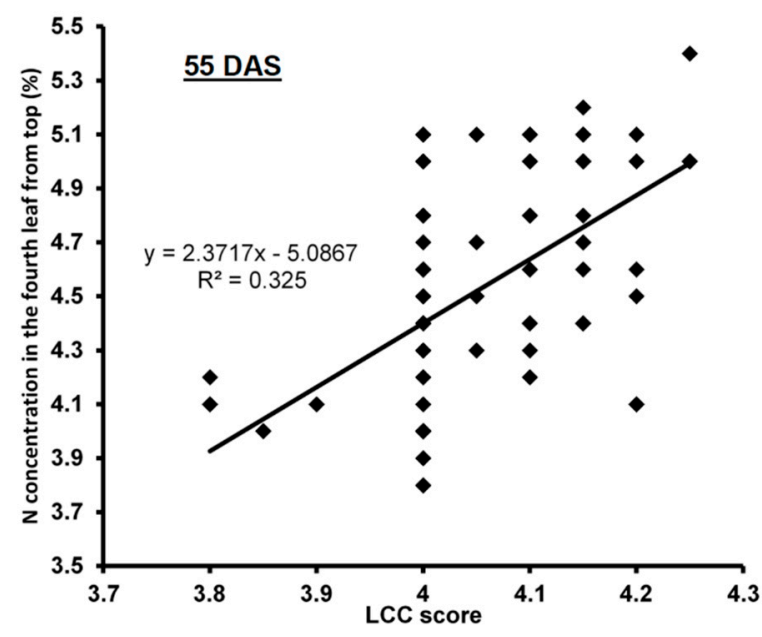

Figure 2. Cont. 


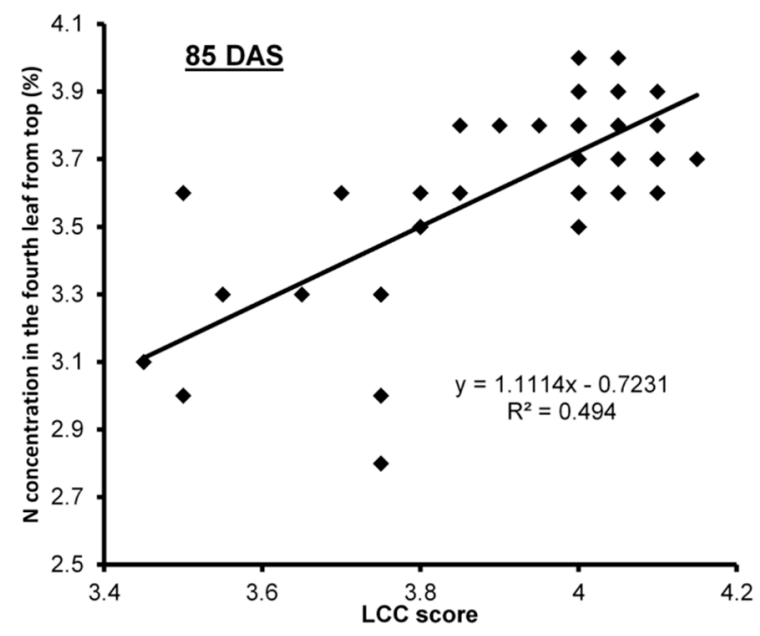

Figure 2. Relationship between LCC scores and N concentration in the fourth leaf from top of plants at 55 and 85 DAS of Bt cotton at Ludhiana, India in 2016 and 2017.

\subsection{Leaf Greenness as Influenced by Fertilizer N Additions}

By the time the cotton crop reached 85 DAS, the LCC score of the fourth leaf from the top of the main stem, measured at 55 days, had reduced. This trend was true for all the fertilizer $\mathrm{N}$ treatments (Table 2). At 55 DAS, the mean LCC score over the years ranged between 3.85 in the no $\mathrm{N}$ control treatment and 4.17 in the treatment receiving $75 \mathrm{~kg} \mathrm{~N} \mathrm{ha}^{-1}$ after 40 DAS. Among the different treatments, the LCC score at 55 DAS was maintained above the critical level of 4.1 in the treatments in which 60 and $75 \mathrm{~kg} \mathrm{~N} \mathrm{ha}^{-1}$ were applied on the 40-day-old crop (treatments T10 to T13) so that only $30 \mathrm{~kg} \mathrm{~N} \mathrm{ha}^{-1}$ was applied at the end of 55 days. The LCC score after 55 DAS was between 3.8 and 4.1 in the treatments receiving 30 or $45 \mathrm{~kg} \mathrm{~N} \mathrm{ha}^{-1}$ at 40 days of the crop (treatments $\mathrm{T} 6$ to T9), indicating that an LCC-based dose of $45 \mathrm{~kg} \mathrm{~N} \mathrm{ha}^{-1}$ was delivered at this stage (Table 2). Thus, in comparison with the application of the recommended $75 \mathrm{~kg} \mathrm{~N} \mathrm{ha}^{-1}$ both at 40 and 55 DAS for Bt cotton in north-western India, in the SSNM treatments receiving an LCC-guided dose of fertilizer $\mathrm{N}$ only by 55 DAS (T6, T8, T10 and T12), a 30 to $50 \%$ less total amount of fertilizer $\mathrm{N}$ was applied than $150 \mathrm{~kg} \mathrm{~N} \mathrm{ha}^{-1}$ (Table 2).

The LCC score in treatments T7 and T9 was between 3.7 and 4.0 at 85 DAS; hence, $45 \mathrm{~kg} \mathrm{~N} \mathrm{ha}^{-1}$ was applied. The LCC score in treatments T11 and T13, on the other hand, was greater than 4.0, resulting in an LCC-guided dose of only $30 \mathrm{~kg} \mathrm{~N} \mathrm{ha}^{-1}$. Thus, in treatments T7, T9, T11 and T13, the total quantity of fertiliser N applied was only 10 to $20 \%$ less than $150 \mathrm{~kg} \mathrm{~N} \mathrm{ha}^{-1}$, the blanket recommended dose in the region, when the LCC-guided fertiliser $\mathrm{N}$ doses were administered both at 55 and 85 DAS (Table 2).

\subsection{Total N Uptake at Maturity, Seed Cotton Yield and Leaf N Concentration}

As shown in Figure 3, the total N uptake by Bt cotton was reflected in the seed cotton yield as well as the $\mathrm{N}$ concentration in the fourth leaf from the top both at 55 and 85 DAS, the two different growth stages. As was expected, the $\mathrm{R}^{2}$ for the relationship between the total $\mathrm{N}$ uptake and the leaf $\mathrm{N}$ concentration was higher at 85 days than that at 55 DAS as the former was closer to the maturity of the crop. These relationships strongly suggested that fertilizer $\mathrm{N}$ management considering the percent $\mathrm{N}$ in a leaf corresponding with the shade number of the leaf colour chart should lead to an adequate total $\mathrm{N}$ uptake by the crop, which subsequently can be translated into a respectable yield level of the crop. 


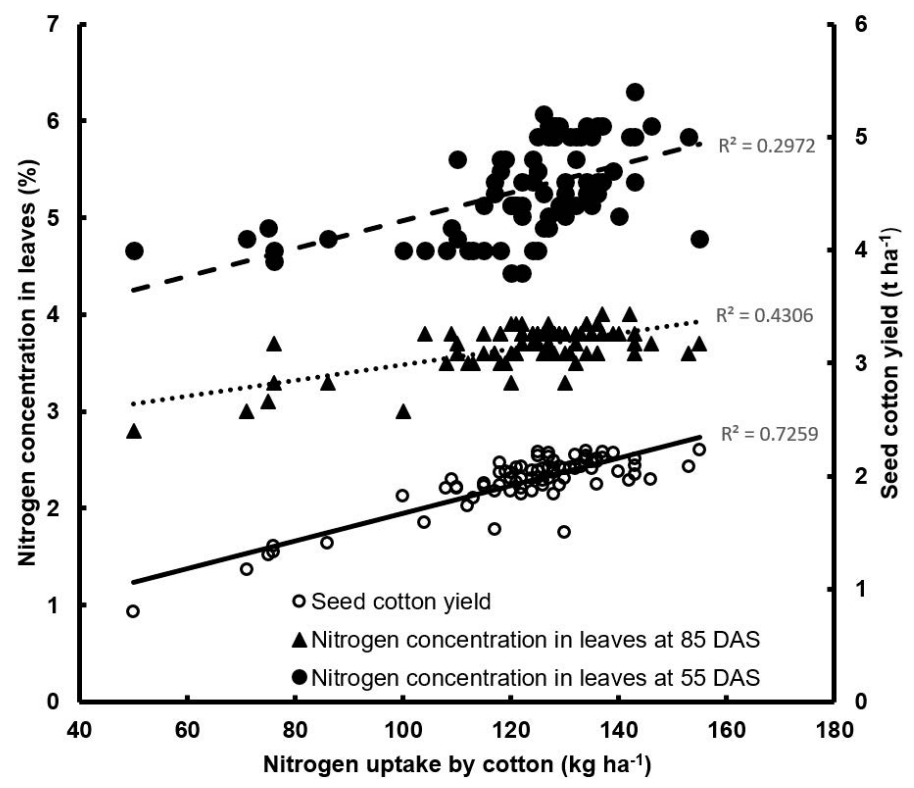

Figure 3. Cotton seed yield ( $\mathrm{t} \mathrm{ha} \mathrm{a}^{-1}$ ) and $\mathrm{N}$ concentration (\%) in the fourth leaf from the top after 55 and 85 DAS of Bt cotton related to the total N uptake at maturity at Ludhiana, India in 2016 and 2017.

\subsection{Crop Response to LCC-Based Site-Specific Fertilizer N Management}

The no $\mathrm{N}$ control treatment showed chlorosis of old leaves after 55 DAS and it became acute after another $30 \mathrm{DAS}$. Averaged over the years, no $\mathrm{N}$ plots recorded a $42 \%$ reduction in the seed cotton yield compared with the plots receiving $150 \mathrm{~kg} \mathrm{~N} \mathrm{ha}^{-1}$ (Table 3), thus exhibiting a response $\mathrm{N}$ application. The response of $\mathrm{Bt}$ cotton to increasing amounts of fertilizer $\mathrm{N}$ when half was applied at 40 days and the other half at 55 DAS (treatments $\mathrm{T} 1$ to T5) is shown in Figure 4. The seed cotton yield improved up to an application of $150 \mathrm{~kg} \mathrm{~N} \mathrm{ha}^{-1}$ but a significant yield enhancement was recorded between the 90 and $150 \mathrm{~kg} \mathrm{~N} \mathrm{ha}^{-1}$ application levels. 
Table 3. Effect of different site-specific $N$ management options based on fixed-time adjustable-dose fertilizer $\mathrm{N}$ treatments and fixed fertilizer $\mathrm{N}$ doses on the yield, sustainable yield index and agronomic efficiency beside the recovery efficiency of fertilizer $\mathrm{N}$ in Bt cotton variety $\mathrm{RCH} 650$ in the experiments conducted in 2016 and 2017 at Ludhiana, India.

\begin{tabular}{|c|c|c|c|c|c|c|c|c|}
\hline \multirow{3}{*}{ Treatment } & \multicolumn{4}{|c|}{ Nitrogen Applied (kg ha $\left.{ }^{-1}\right)$ in Both 2016 and 2017} & \multirow{3}{*}{$\begin{array}{c}\text { Seed Cotton } \\
\text { Yield }\left(\mathrm{t} \mathrm{ha} \mathrm{a}^{-1}\right) \\
\text { Pooled over } \\
\text { Two Years }\end{array}$} & \multirow{3}{*}{$\begin{array}{l}\text { Sustainable } \\
\text { Yield Index } \\
\text { Pooled over } \\
\text { Two Years }\end{array}$} & \multirow{3}{*}{$\begin{array}{l}\text { Agronomic Efficiency (kg } \\
\text { Cotton Seed Yield/kg N } \\
\text { Applied) Pooled over } \\
\text { Two Years }\end{array}$} & \multirow{3}{*}{$\begin{array}{c}\text { Recovery } \\
\text { Efficiency }(\% \\
\text { Pooled over } \\
\text { Two Years }\end{array}$} \\
\hline & \multicolumn{3}{|c|}{ DAS } & \multirow{2}{*}{ Total } & & & & \\
\hline & 40 & 55 & 85 & & & & & \\
\hline $\mathrm{T} 1$ & 0 & 0 & 0 & 0 & 1.44 & 45.4 & - & - \\
\hline $\mathrm{T} 2$ & 30 & 30 & - & 60 & 2.02 & 70.2 & 9.6 & 69 \\
\hline T3 & 45 & 45 & - & 90 & 2.30 & 85.6 & 9.6 & 59 \\
\hline $\mathrm{T} 4$ & 60 & 60 & - & 120 & 2.43 & 90.1 & 8.3 & 47 \\
\hline T5 & 75 & 75 & - & 150 & 2.48 & 94.2 & 6.9 & 40 \\
\hline T6 & 30 & $45\left(\mathrm{Ad}_{1}\right)^{\dagger}$ & - & 75 & 2.15 & 77.0 & 9.5 & 61 \\
\hline $\mathrm{T} 7$ & 30 & $45\left(\mathrm{Ad}_{1}\right)$ & $45\left(\mathrm{Ad}_{2}\right)^{\ddagger}$ & 120 & 2.40 & 87.1 & 8.1 & 41 \\
\hline T8 & 45 & $45\left(\mathrm{Ad}_{1}\right)$ & - & 90 & 2.33 & 86.2 & 9.8 & 58 \\
\hline T9 & 45 & $45\left(\mathrm{Ad}_{1}\right)$ & $45\left(\mathrm{Ad}_{2}\right)$ & 135 & 2.38 & 87.6 & 7.0 & 42 \\
\hline T10 & 60 & $30\left(\mathrm{Ad}_{1}\right)$ & - & 90 & 2.37 & 87.6 & 10.4 & 62 \\
\hline T11 & 60 & $30\left(\mathrm{Ad}_{1}\right)$ & $30\left(\mathrm{Ad}_{2}\right)$ & 120 & 2.42 & 88.3 & 7.3 & 45 \\
\hline T12 & 75 & $30\left(\mathrm{Ad}_{1}\right)$ & - & 105 & 2.40 & 88.6 & 9.1 & 57 \\
\hline $\mathrm{T} 13$ & 75 & $30\left(\mathrm{Ad}_{1}\right)$ & $30\left(\mathrm{Ad}_{2}\right)$ & 135 & 2.46 & 89.6 & 7.6 & 48 \\
\hline $\begin{array}{c}\text { LSD } \\
(p=0.05)\end{array}$ & & & & & 0.176 & & 2.28 & 12.1 \\
\hline
\end{tabular}

${ }^{+} \mathrm{Ad}_{1}$ : adaptable quantity of 30, 45 or $60 \mathrm{~kg} \mathrm{~N} \mathrm{ha}^{-1}$ depending on LCC score $>4.1$, between 3.8 and 4.1 and $<3.8$, respectively. $\ddagger \mathrm{Ad}_{2}$ : adaptable quantity of 30,45 and $60 \mathrm{~kg} \mathrm{~N} \mathrm{ha}^{-1}$ depending on LCC score $>4.0$, between 3.7 and 4.0 and $<3.7$, respectively.

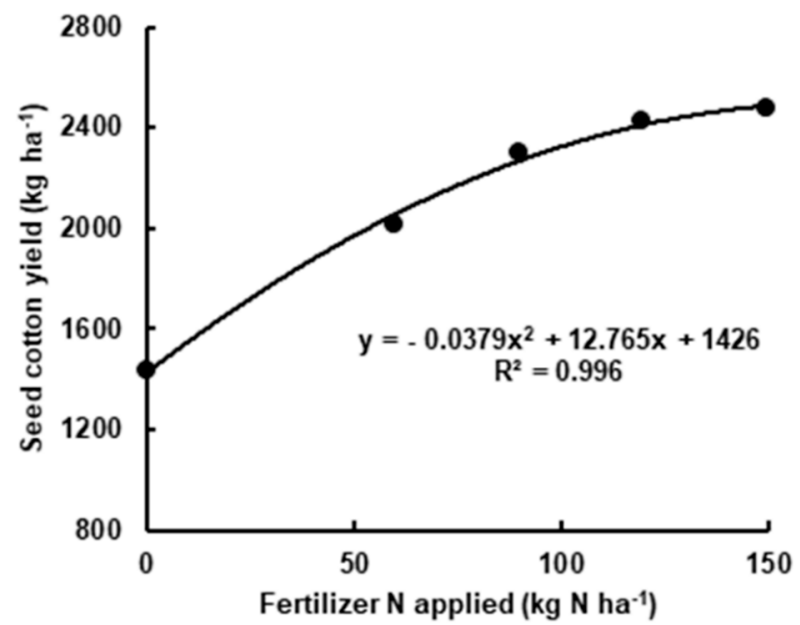

Figure 4. Yield of seed cotton as a function of increasing amounts of fertilizer $\mathrm{N}$ added one half at 40 days and the other half at 55 DAS at Ludhiana, India in 2016 and 2017.

Two categories of site-specific $\mathrm{N}$ management scenarios for Bt cotton were investigated in the present study after applying different fertilizer $\mathrm{N}$ doses $40 \mathrm{DAS}$, an LCC-based fertilizer N application at 55 DAS or at both 55 as well as 85 DAS, the critical growth stages. The results pertaining to the seed cotton yield, sustainability index and fertilizer $\mathrm{N}$ use efficiency parameters as influenced by different site-specific $\mathrm{N}$ management treatments are listed in Table 3. In the first category treatments (T6, T8, T10, T12), although LCC-based $45 \mathrm{~kg} \mathrm{~N} \mathrm{ha}^{-1}$ was applied along with both $30 \mathrm{~kg} \mathrm{~N} \mathrm{ha}^{-1}$ (T6) and $45 \mathrm{~kg} \mathrm{~N} \mathrm{ha}^{-1}$ (T8) after 40 DAS, the seed cotton yield with treatment T6 was significantly less than all the site-specific $\mathrm{N}$ management treatments (Table 3). The seed cotton yield observed with treatment T8 was on a par with treatments T10 and T12, in which 60 and $75 \mathrm{~kg} \mathrm{~N} \mathrm{ha}^{-1}$ were applied after 40 DAS, respectively, but after 55 DAS, LCC-based $30 \mathrm{~kg} \mathrm{~N} \mathrm{ha}^{-1}$ was 
applied to both. These results suggested that when the LCC was used for the application of the fertilizer $\mathrm{N}$ dose after 55 DAS, the $\mathrm{N}$ applied at $40 \mathrm{DAS}$ must be $45 \mathrm{~kg} \mathrm{~N}^{-1}$ or greater to obtain statistically similar yields as that obtained with the recommended $150 \mathrm{~kg} \mathrm{~N} \mathrm{ha}^{-1}$. The sustainable yield index was also the lowest when one-fifth of the recommended dose of $\mathrm{N}$ was applied at 40 DAS and LCC-based fertilizer was applied at 55 DAS (Table 3). In the second category of site-specific $\mathrm{N}$ management treatments in which LCC-based fertilizer $\mathrm{N}$ doses were applied both at 55 and 85 DAS, the seed cotton yields with all four treatments (T7, T9, T11, T13) were on a par with the optimum yield levels obtained with $150 \mathrm{~kg} \mathrm{~N} \mathrm{ha}^{-1}$ (Table 3). The total amount of fertilizer $\mathrm{N}$ applied in these treatments, although less than $150 \mathrm{~kg} \mathrm{~N} \mathrm{ha}{ }^{-1}$ by 10 to $20 \%$, was greater than the total quantity of fertilizer $\mathrm{N}$ applied in the three treatments in the first category that produced optimum seed cotton yields.

\section{5. $\mathrm{N}_{2} \mathrm{O}$ Emissions}

In cropped ecosystems, the amount of nitrogen fertiliser used is the best measure of $\mathrm{N}_{2} \mathrm{O}$ emissions. The CCAFS-MOT model revealed that nitrogen management treatments differed in terms of $\mathrm{N}_{2} \mathrm{O}$ emissions $\left(\mathrm{kg} \mathrm{CO}_{2}\right.$ eq ha $\left.{ }^{-1}\right)$ (Table 4). The model produced $\mathrm{N}_{2} \mathrm{O}$ emissions of $101.4 \mathrm{~kg} \mathrm{CO}_{2} \mathrm{eq} \mathrm{ha}^{-1}$ in the no $\mathrm{N}$ treatment, which included no $\mathrm{N}$ fertilizer. Unusually amplified values of estimated $\mathrm{N}_{2} \mathrm{O}$ emissions were found under soil test-based $\mathrm{N}\left(150 \mathrm{~kg} \mathrm{~N} \mathrm{ha}^{-1}\right)$ followed by T9 (135 kg N ha ${ }^{-1}$, i.e., $45 \mathrm{~kg}$ at 40 DAS followed by an LCC-based $\mathrm{N}$ application of $45 \mathrm{~kg}$ each at 55 and 85 DAS) whereas those under T8 (90 kg N $\mathrm{ha}^{-1}$, i.e., $45 \mathrm{~kg}$ after 40 DAS followed by an LCC-based $\mathrm{N}$ application of $45 \mathrm{~kg}$ at 55 DAS) or T10 (90 kg N ha ${ }^{-1}$, i.e., $60 \mathrm{~kg}$ at 40 DAS followed by an LCC-based $\mathrm{N}$ application of $30 \mathrm{~kg}$ at $55 \mathrm{DAS}$ ) were lowest (Table 4). The LCC-based N application helped to lower the $\mathrm{N}_{2} \mathrm{O}$ emissions by $66.8 \%$ over the soil test-based $\mathrm{N}$ application without any yield loss.

Table 4. Effect of need-based $\mathrm{N}$ management using a threshold approach on an average estimated $\mathrm{N}_{2} \mathrm{O}$ emission ( $\mathrm{kg} \mathrm{CO}_{2} \mathrm{eq} \mathrm{ha}^{-1}$ ) in Bt cotton variety $\mathrm{RCH} 650$ in the experiments conducted in 2016 and 2017.

\begin{tabular}{|c|c|c|c|c|c|c|}
\hline \multirow{3}{*}{ Treatment } & \multicolumn{4}{|c|}{$\begin{array}{c}\text { Nitrogen Broadcasted }\left(\mathrm{kg} \mathrm{ha}^{-1}\right) \text { in Both } \\
2016 \text { and } 2017\end{array}$} & \multirow{3}{*}{$\begin{array}{c}\text { Seed Cotton } \\
\text { Yield }\left(t \text { ha }^{-1}\right) \\
\text { Pooled over } \\
\text { Two Years }\end{array}$} & \multirow{3}{*}{$\begin{array}{c}\mathrm{N}_{2} \mathrm{O} \text { Emission } \\
\left(\mathrm{kg} \mathrm{CO}_{2} \text { eq ha }{ }^{-1}\right) \\
\text { Pooled over } \\
\text { Two Years }\end{array}$} \\
\hline & \multicolumn{3}{|c|}{ DAS } & \multirow{2}{*}{ Total } & & \\
\hline & 40 & 55 & 85 & & & \\
\hline $\mathrm{T} 1$ & 0 & 0 & 0 & 0 & 1.44 & 101 \\
\hline T5 & 75 & 75 & - & 150 & 2.48 & 1006 \\
\hline $\mathrm{T} 8$ & 45 & $45\left(\mathrm{Ad}_{1}\right)$ & - & 90 & 2.33 & 603 \\
\hline T9 & 45 & $45\left(\mathrm{Ad}_{1}\right)$ & $45\left(\mathrm{Ad}_{2}\right)$ & 135 & 2.38 & 898 \\
\hline $\mathrm{T} 10$ & 60 & $30\left(\mathrm{Ad}_{1}\right)$ & - & 90 & 2.37 & 603 \\
\hline T11 & 60 & $30\left(\mathrm{Ad}_{1}\right)$ & $30\left(\mathrm{Ad}_{2}\right)$ & 120 & 2.42 & 794 \\
\hline
\end{tabular}

\section{Discussion}

For all the fertilizer $\mathrm{N}$ treatments, the LCC score at 55 DAS was higher than that obtained after 85 DAS (Table 2). This trend reflected the remobilisation of $\mathrm{N}$ from the leaves to the apical bud or nearest developing bolls. Zhu and Oosterhuis [19] reported that developing bolls became an $\mathrm{N}$ sink post-flowering and $\mathrm{N}$ was supplied to bolls partly by the subtending leaves. Wood et al. [9] also reported a decrease in leaf greenness after early flowering towards mid-flowering.

The response of Bt cotton to increasing amounts of fertilizer $\mathrm{N}$ with one half applied after 40 days and the other half after 55 DAS (treatments T1 to T5) as shown in Table 3 and Figure 4 was in line with already published studies. Venugopalan et al. [20] reviewed different studies with Bt cotton in India and revealed that the optimum response of irrigated Bt cotton to the application of $\mathrm{N}$ was observed between 90 and $150 \mathrm{~kg} \mathrm{ha}^{-1}$. Gangaiah et al. [21] reported that Bt cotton responded to fertilizer $\mathrm{N}$ application up to $120 \mathrm{~kg} \mathrm{ha}^{-1}$. 
The wide range in the optimum fertilizer $\mathrm{N}$ rate of application to Bt cotton suggests that in any given field, a standard fertilizer $\mathrm{N}$ recommendation would most likely not be able to provide optimum $\mathrm{N}$ nutrition to the crop because of the variability in the $\mathrm{N}$-supplying capacity of the soil in different fields. Standard fertilizer $\mathrm{N}$ recommendations are formulated in such a way that optimum yields can be produced in all fields in the region. Thus, in several fields, the standard recommendations will lead to the application of fertilizer $\mathrm{N}$ greater than the actual $\mathrm{N}$ need. Although the application of less fertilizer $\mathrm{N}$ can lead to a yield reduction in proportion to the fertilizer shortfall and reduced soil $\mathrm{N}$ pool, overfertilization can result in excessive vegetative growth and a delay in maturity as well as adversely affecting the lint yield and fibre quality [9]. As the application of sufficient $\mathrm{N}$ only can ensure an optimum growth [22] and the yield of cotton and high $\mathrm{N}$ use efficiency [23], ideally, the optimum fertilizer $\mathrm{N}$ dose needs to be determined for each individual field.

The broadcasting of 45 or $60 \mathrm{~kg} \mathrm{~N}^{-1}$ at 40 DAS and an LCC-based N application at 55 DAS is a sound SSNM strategy for Bt cotton in north-western India to produce optimum yields with high fertilizer $\mathrm{N}$ use efficiency suggests that ensuring an adequate plant $\mathrm{N}$ status at flowering is very important. According to Oosterhuis et al. [24], nutrient inadequacy at the flowering stage of cotton may result in a reduced and variable yield. $\mathrm{Wu}$ et al. [10] reported that the leaf spectral properties in cotton must be measured at early flowering to ensure that sufficient time is allowed to alleviate any $\mathrm{N}$ deficiency. The seed cotton yields among all the site-specific $\mathrm{N}$ management treatments except $\mathrm{T} 6 \mathrm{did}$ not differ significantly. However, due to a variation in the amount of fertilizer $\mathrm{N}$ applied only at 55 or both at 55 and 85 DAS, a higher agronomic efficiency ( 9.1 to $10.4 \mathrm{~kg}$ cotton seed yield per $\mathrm{kg} \mathrm{N}$ applied) was recorded by applying LCC-based fertilizer $\mathrm{N}$ at 55 DAS rather than at both 55 and 85 DAS (7.0 to $8.1 \mathrm{~kg}$ cotton seed yield per $\mathrm{kg} \mathrm{N}$ applied) (Table 3). Due to the same reason, the data pertaining to the $\mathrm{N}$ recovery efficiency also showed a similar trend among the different treatments. Although $\mathrm{N}$ recovery efficiency in the treatments where LCC-based fertilizer $\mathrm{N}$ was applied only at 55 DAS ranged between 57 to $61 \%$, in treatments in which LCC-based fertilizer N doses were applied both at 55 and 85 DAS it ranged between 41 and $48 \%$ (Table 3 ).

Wang [25] reported the usefulness of applying additional $\mathrm{N}$ at early flowering/flowering and at peak flowering stages for cotton cultivars in China. It was observed that delaying fertilizer applications beyond 55 DAS reduced the yield, particularly under wet conditions, due to a delayed maturity and rank growth. This was evident also in the present study as insignificant yield differences and significantly lower $\mathrm{N}$ recovery efficiencies were recorded for the treatments in which LCC-adjustable doses of $\mathrm{N}$ were applied at both 55 and 85 DAS compared with the treatments in which an LCC-adjustable dose of $\mathrm{N}$ was applied only at 55 DAS. The only exception was where too little fertilizer was applied at 40 DAS (T6). Thus, the treatments in which LCC-based fertilizer N was applied at 85 DAS (T7, T9, T11 and T13) are not suitable for site-specific $\mathrm{N}$ management strategies for Bt cotton in north-western India. As the application of more than $60 \mathrm{~kg} \mathrm{~N} \mathrm{ha}^{-1}$ at 40 DAS did not increase the yield further but resulted in a higher total fertilizer $\mathrm{N}$ application (T12 versus T8 and T10), this strategy led to reduced fertilizer $\mathrm{N}$ use efficiency.

A better utilisation of fertilizer $\mathrm{N}$ and its absorption adding an LCC-based $\mathrm{N}$ application not only resulted in a yield on a par with soil test-based $\mathrm{N}$ applications but also reduced $\mathrm{N}_{2} \mathrm{O}$ emissions. Therefore, the application of 45 or $60 \mathrm{~kg} \mathrm{~N} \mathrm{ha}^{-1}$ after 40 DAS and LCC-based $\mathrm{N}$ additions at 55 DAS constituted the most appropriate site-specific $\mathrm{N}$ management strategy. This strategy can easily be followed by farmers in the region because it involves the use of the LCC only at one stage. As comparing the colour of leaves with colour shades on the LCC can be performed by virtually anyone, this strategy for fertilizer $\mathrm{N}$ management in Bt cotton has the potential to become popular with farmers. Once farmers understand that this strategy does not allow the application of more fertilizer $\mathrm{N}$ than is needed by the crop, it may be adopted by large number of farmers. 


\section{Conclusions}

The LCC can reliably provide an estimate of the $\mathrm{N}$ content in the leaves of $\mathrm{Bt}$ cotton by visually comparing the reflection of light from the leaf and the six shades of green colour on the chart. Based on the principles of site-specific $\mathrm{N}$ management involving the threshold leaf greenness at 55 and 85 days after sowing, the LCC can be used to guide fertilizer N application in Bt cotton as per the need of the crop in a given field. The broadcasting of 45 or $60 \mathrm{~kg} \mathrm{~N} \mathrm{ha}^{-1}$ after 40 days of sowing and an LCC-based N addition at 55 days after sowing has emerged as the appropriate site-specific $\mathrm{N}$ management strategy for Bt cotton in north-western India. Following this strategy, farmers should be able produce lint and seed cotton yields comparable with those with the endorsed dose of $150 \mathrm{~kg} \mathrm{~N} \mathrm{ha}^{-1}$, but only with the use of $60 \%$ of the recommended N. Hence, this site-specific $\mathrm{N}$ management strategy on an LCC basis also results in a higher agronomic recovery as well as $\mathrm{N}$ use efficiency along with remarkably lowered nitrous oxide emissions than by applying fertilizer $\mathrm{N}$ following the standard recommendation.

Author Contributions: Conceptualisation, R.K.G., A.S. and R.B.; methodology, R.K.G., A.S. and B.-S.; software, R.K.G., A.A.A.-H. and B.-S.; validation, R.K.G., A.S. and R.B.; formal analysis, R.K.G.; investigation, R.K.G.; resources, M.H.S., R.K. and A.A.A.-H.; data curation, R.K.G., M.H.S., A.S., R.K. and R.B.; writing - original draft preparation, R.K.G., A.S. and R.B.; writing-review and editing, M.H.S., A.A.A.-H., R.K., A.S. and R.B.; visualisation, A.S. and R.B.; supervision, R.B.; funding acquisition, A.A.A.-H. and M.H.S. All authors have read and agreed to the published version of the manuscript.

Funding: The research was support by the Researchers Supporting Project number (RSP-2021/186), King Saud University, Riyadh, Saudi Arabia.

Institutional Review Board Statement: Not applicable.

Informed Consent Statement: Not applicable.

Data Availability Statement: The data presented in this study are available in the article.

Acknowledgments: The authors would like to extend their sincere appreciation to the Researchers Supporting Project number (RSP-2021/186), King Saud University, Riyadh, Saudi Arabia.

Conflicts of Interest: The authors declare that they have no conflict of interest.

\section{References}

1. Pettigrew, W.T.; Adamczyk, J.J., Jr. Nitrogen fertility and planting date effects on lint yield and Cry1Ac (Bt) endotoxin production. Agron. J. 2006, 98, 691-697. [CrossRef]

2. Bijay-Singh; Varinderpal-Singh; Ali, A.M. Site-specific fertilizer nitrogen management in cereals in South Asia. Sust. Agric. Rev. 2020, 39, 137-178.

3. Punjab Agricultural University. Package of Practices for the Crops of Punjab—Kharif 2016; Punjab Agricultural University: Ludhiana, India, 2016; Volume 33.

4. Cassman, K.G.; Dobermann, A.; Walters, D.T. Agroecosystems, nitrogen-use efficiency, and nitrogen management. AMBIO 2002, 31, 132-140. [CrossRef] [PubMed]

5. Bijay-Singh; Ali, A.M. Using hand-held chlorophyll meters and canopy reflectance sensors for fertilizer nitrogen management in cereals in small farms in developing countries. Sensors 2020, 20, 1127. [CrossRef] [PubMed]

6. Fageria, N.K.; Baligar, V.C. Enhancing nitrogen use efficiency in crop plants. Adv. Agron. 2005, 88, 97-185.

7. Yang, W.H.; Peng, S.; Huang, J.; Sanico, A.L.; Buresh, R.J.; Witt, C. Using leaf color charts to estimate leaf nitrogen status of rice. Agron. J. 2003, 95, 212-217. [CrossRef]

8. Tian, H.; Xu, R.; Canadell, J.G.; Thompson, R.L.; Winiwarter, W.; Suntharalingam, P.; Yao, Y. A comprehensive quantification of global nitrous oxide sources and sinks. Nature 2020, 586, 248-256. [CrossRef] [PubMed]

9. Wood, C.W.; Tracy, P.W.; Reeves, D.W.; Edmisten, K.L. Determination of cotton nitrogen status with a hand held chlorophyll meter. J. Plant Nutr. 1992, 15, 1435-1448. [CrossRef]

10. $\mathrm{Wu}$, F.B.; Wu, L.H.; Xu, F.H. Chlorophyll meter to predict nitrogen sidedress requirements for short-season cotton (Gossypium hirsutum L.). Field Crops Res. 1998, 56, 309-314.

11. Rosolem, C.A.; Mellis, V. Monitoring nitrogen nutrition in cotton. Rev. Bras. Ciênc. Do Solo 2010, 34, 1601-1607. [CrossRef]

12. Arun Shankar; Gupta, R.K.; Bijay-Singh. Site-specific fertilizer nitrogen management in Bt cotton using chlorophyll meter. Exp. Agric. 2020, 56, 397-406. 
13. Muharam, F.M.; Maas, S.J.; Bronson, K.F.; Delahunty, T. Estimating cotton nitrogen nutrition status using leaf greenness and ground cover information. Remote Sens. 2015, 7, 7007-7028. [CrossRef]

14. Jackson, M.L. Soil Chemical Analysis; Prentice Hall of India: New Delhi, India, 1973.

15. Walkley, A. A critical examination of a rapid method for determining organic carbon in soils-effect of variations in digestion conditions and of inorganic soil constituents. Soil Sci. 1947, 63, 251-264. [CrossRef]

16. Arun Shankar; Gupta, R.K.; Bijay-Singh. Establishing indicator leaf and its threshold values for need based nitrogen management using chlorophyll meter and leaf color chart in Bt cotton. J. Plant Nutr. 2019, 42, 186-201.

17. Yoshida, S.; Forno, D.A.; Cock, D.H.; Gomez, K.A. Laboratory Manual for Physiological Studies of Rice, 3rd ed.; International Rice Research Institute: Los Baños, Phillipines, 1976.

18. Baligar, V.C.; Fageria, N.K.; He, Z.L. Nutrient use efficiency in plants. Comm. Soil Sci. Plant Anal. 2001, 32, 921-950. [CrossRef]

19. Zhu, B.; Oosterhuis, D.M. Nitrogen distribution within a sympodial branch of cotton. J. Plant Nutr. 1992, 15, 1-14. [CrossRef]

20. Venugopalan, M.V.; Blaise, D.; Yadav, M.S.; Deshmukh, R. Fertilizer response and nutrient management strategies for cotton. Indian J. Fert. 2011, 7, 82-94.

21. Gangaiah, B.; Ahlawat, I.P.S.; Babu, M.B.B.P. Response of nitrogen fertilization on Bt and non-Bt cotton (Gossypiumhirsutum) hybrids. SAARC J. Agric. 2013, 11, 121-132. [CrossRef]

22. Schils, R.; Verhagen, A.; Aarts, H.; Kuikman, P.; Sebek, L. Effect of improved nitrogen management on greenhouse gas emissions from intensive dairy systems in The Netherlands. Glob. Chang. Biol. 2006, 12, 382-391. [CrossRef]

23. Liu, X.; Zhang, Y.; Han, W.; Tang, A.; Shen, J.; Cui, Z.; Vitousek, P.; Erisman, J.W.; Goulding, K.; Christie, P.; et al. Enhanced nitrogen deposition over China. Nature 2013, 494, 459-462. [CrossRef]

24. Oosterhuis, D.M.; Chipamaunga, J.; Bate, G.C. Nitrogen uptake of field grown cotton I. Distribution in plant components in relation to fertilization and yield. Exp. Agric. 1983, 19, 91-101. [CrossRef]

25. Wang, Z.L. Effects of EDTA on biological characteristics in cotton. China Cotton 1992, 19, 29-30. 